\title{
THEAMERICAN ILLNESS
}


This page intentionally left blank 


\section{EDITED BY F.H. BUCKLEY}

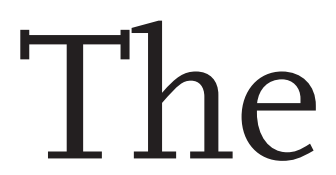

American

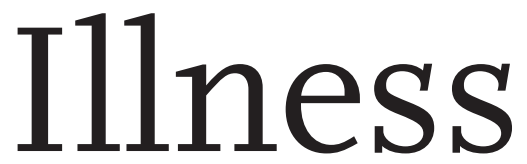

Essays on the Rule of Law 
Published with assistance from the foundation established in memory of Philip Hamilton McMillan of the Class of 1894, Yale College.

Copyright (C) 2013 by F.H. Buckley.

All rights reserved.

This book may not be reproduced, in whole or in part, including illustrations, in any form (beyond that copying permitted by Sections 107 and 108 of the U.S. Copyright Law and except by reviewers for the public press), without written permission from the publishers.

Yale University Press books may be purchased in quantity for educational, business, or promotional use. For information, please e-mail sales.press@yale.edu (U.S. office) or sales@yaleup.co.uk (U.K. office).

Designed by James J. Johnson.

Set in Scala type by Westchester Book Group.

Printed in the United States of America.

Library of Congress Cataloging-in-Publication Data

The American illness : essays on the rule of law /

edited by F.H. Buckley.

pages $\mathrm{cm}$

Includes bibliographical references and index.

ISBN 978-0-300-17521-9

1. Law-United States. I. Buckley, F. H. (Francis H.), 1948-editor of compilation.

$$
\begin{gathered}
\mathrm{KF}_{3} 89 . \mathrm{A}_{44} 2013 \\
340^{\prime} .11-\mathrm{dc} 23 \\
2012037080
\end{gathered}
$$

A catalogue record for this book is available from the British Library.

This paper meets the requirements of ANSI/NISO Z39.48-1992

(Permanence of Paper). 
For Esther and Sarah 
This page intentionally left blank 